\title{
Labour and globalisation
}

Complexity and transformation

Ronaldo Munck*
https://orcid.org/0000-0002-7117-1099

The future of labour in the era of late globalisation has been transformed as the rest of social life has by the Covid-19 pandemic. We hear repeatedly now (May 2021) that we will have to live with Covid-19 and that there will be a "new normal". But what does that mean in the context of labour and the labour movement? Many psychologists tell us there is a huge tendency after a crisis for people to want to "get back to normal" (see Taylor, 2019). But is that even possible after Covid-19? Does it mean we should just strive to return to the status quo? Covid-19 is a health crisis but also a social, political and cultural one, and will, of course, have a major economic impact, not least on the world of work that has been seriously disrupted.

\section{Back to normal?}

To answer these questions we might need to think through the relationship between the normal and the pathological, based on the seminal work on the subject by philosopher of science Georges Canguilhem, who argued that "We shall say that the healthy man [sic] does not become sick insofar as he is healthy. No healthy man becomes sick, for he is sick only insofar as his health abandons him and in this he is not healthy. The so-called healthy man thus is not healthy. His health is an equilibrium which he redeems on inceptive ruptures. The menace of disease is

\footnotetext{
* Dublin City University, Dublin, Ireland.
} 
one of the components of health" (Canguilhem, 1991, p. 56). How does this relate to the contemporary workplace and work relations? Was it healthy and then did it become pathological because of the coronavirus? For Canguilhem, being healthy and being "normal" are not altogether equivalent since the pathological is but one kind of normal. Being normal also implies being normative but then being healthy (as in a body) implies being able to transcend the norm. To be in good health means being able to fall sick and recover, according to Canguilhem. So, was the world of work and work relations really healthy before the coronavirus? Does the current pathology signal a simple accentuation of normal phenomena or does it lead to a "crisis" defined in medical terms as "the turning point of a disease when an important change takes place, indicating either recovery or death"? The Covid-19 crisis has brought home the essential role that workers play in keeping the wheels of society going, not least health workers of course but all those workers who could not "work from home" as many white-collar workers were encouraged to do.

We might finally, at this point, take up a potentially positive reading of "crisis", which is implicit in its original definition as "the turning point for better or worse in an acute disease or fever" (Merriam-Webster, 2020). An alternative scenario would be that people learn from the crisis that they are living through and call for fundamental system change. Rebecca Solnit (2010) has argued that the Mexico City earthquake of 1985 and the 2005 Hurricane Katrina disaster in the us unleashed great reserves of human solidarity, energetic improvisation and purposeful intent that augured well for the future. In relation to the current Covid-19 crisis, Solnit argues that "ordinary life before the pandemic was already a catastrophe of desperation and exclusion for too many human beings, an environmental and climate catastrophe, an obscenity of inequality" (Solnit, 2020) so that fundamental change is overdue and a return to "business as usual" is not an option. In other words, we may not wish to return to "normal", and the "pathological" period we are living through could help us create the conditions for a new, more humane social order.

It was within an already chaotic situation that the Covid-19 crisis emerged and sent real shockwaves through the global economy, now threatened imminently by a depression that would dwarf that of the 1930s (see IMF, 2020). In March 2020 we witnessed a near-fatal crisis in the financial system, kept going only through spectacular interventions by the Federal Reserve in the Us, the Bank of England and the European Central Bank. Production and employment plummeted with the enactment of Covid "lockdowns" and credit contracted dramatically. The question now arises as to whether capitalism can once again rise from its sick-bed and recover its legendary animal spirits? For Adam Tooze, any notion of a unified global order has now dissipated: "we will somehow have to patch together China's one-party 
authoritarianism, Europe's national welfarism and whatever it is the United States will be in the wake of this disaster" (Tooze, 2020). We are certainly a long way from the optimism of 1989-90 when the collapse of communism and the beginning of globalisation painted a rosy future for capitalism. The social impact of the Covid crisis was very rapidly felt. According to the International Labour Organization (ILO, 2020), by March 2020 almost half the global workforce - 1.6 billion people - were in immediate danger of having their livelihoods destroyed by the economic impact of Covid-19, and the International Monetary Fund forecast a 3\% contraction (Guardian, 2020). Of the total global working population of 3.3 billion, about 2 billion work in the "informal economy", often on short-term contracts or in self-employment, and suffered a $60 \%$ collapse in their wages in the first month of the crisis (ILO, 2020). In global terms, we are facing a crisis of livelihoods of unprecedented proportions where a future without income, food or security is on the horizon for many. It is not surprising that forward-thinking economists such as Mariana Mazzucato are calling for a re-think of the global economic order as and when it reboots (Mazzucato, 2020). We now have to see whether the organisations representing workers can rise to the occasion and help forge a progressive post Covid process of social transformation.

The editors of the Global Labour Journal have recently carried out an inventory of the ways in which Covid-19 has impacted on the world of work and the questions posed for a critical study of labour from a global perspective (Cooke et al., 2021). While we still cannot be clear on the outcome (as of May 2021) we can certainly discern dramatic shifts in the nature of workplace relations and the emergence of an extreme wave of exploitation of workers. This is an era of unprecedented complexity with social, economic, political and cultural transformations likely to change the very parameters of work, meaning that a "return to normal" is simply out of the question. The Global Labour editors pose a number of questions for us that will need to be addressed: How is the pandemic reconfiguring the global and the national? How is the pandemic further destabilising distinctions between formal and informal sectors? How has the pandemic exacerbated inequalities and sharpened the class divide? To what extent has the pandemic and responses to it engendered new or revived forms of resistance and organisation among workers? How does the use of digital infrastructures implemented in this crisis alter the labour process? What is their impact on workers? How does the pandemic, and its political and economic effects, affect attempts to address the global ecological crisis, and what does this mean for workers?

These are questions that a number of the articles in this special issue, see above, address either explicitly or implicitly. We are no longer thinking in binary terms of the global North and South as though they were different species of capitalism and therefore subject to different laws of development. The formal/informal divide can- 
not be reduced to a North/South geographical explanation as we see it impacting in both spaces. The development of a digital economy is not, for its part, confined to the once prosperous heartlands of capitalism. The pandemic has both exposed and exacerbated social inequalities and laid bare the predatory inhuman nature of capitalism. There have been defensive mobilisations by workers in many countries for example to demand protective equipment and against coercive practices. What has also come to the fore is the clear realisation that the future of workers and of the planet are interlinked and the climate crisis will now be addressed as a matter of priority.

\section{Current challenges}

Michele Ford provides us with an overview of the achievements of the international labour movement in regards to Asian unions' responses to temporary labour migration that have been stronger and had more impact than one would have perhaps expected. In countries such as Malaysia, Thailand and Honk Kong, where the unions are relatively weak there have been considerable advances when working directly with international migrants, most often supported by the global unions.impact of its interventions on the approaches and practices of the unions with which they worked most closely on migration. In the three countries where they were most active - Hong Kong, Malaysia and Thailand - advancements as a result of these programs are particularly remarkable, given unions' low levels of institutional power in those contexts. This success has then in turn empowered the unions giving them grater mobilising capacity and perhaps legitimacy. In Hong Kong, the union's decision to support a migrant led organisation of foreign domestic workers in alliance with migrant workers NGOs has led to legislative change in regards to the treatment of migrant workers. In Malasysia the recruitment of migrant workers in timber and electronic sectors has greatly energised the unions and even helped reform their bureaucratic internal practices.

Caleb Goods, Andrew Herod, Bradon Ellem, Al Rainnie examine the way the large global production networks of Komatsu and Caterpillar have evolved through internal company logics but have also been shaped by their interactions with the state and, crucially for our purposes, with their workforces. Workers are active players in the unfolding of companies' transnational strategies and not just passive victims of this process. Interestingly we find that Caterpillar has had a much more adversarial relationship with its workforce than Komatsu and managed labour in different ways but in both cases labour helped shape the development of capitalism. Today with the rise of labour-saving robotisation and automation we can expect the labour question 
to become even more central with access to skilled, rather than just cheap labour being crucial to both companies. In the complex politics of scale and the search for a "spatial fix" for the problems of capitalism it may well be that China is not the last stop in that process. High skilled engineers and computer operators, rather than the semi-skilled production line workers of the past, will probably be the lead players in this process and the ongoing struggle between labour and capital. This chapter reminds us that labour shapes capital as much as the other way round and keeps to the fore the question of agency.

For their part Leonardo Mello e Silva', Ricardo Framil Filho and Katiuscia Moreno Galhera examine the way in which cross-border trade union networks operate within transnational corporation through a comparison between various sectors in Brazil such as the metal and chemical, garment, retail, and commercial banking sectors. These union networks are grounded in local instances of global production and target specific transnational corporations. They seek to join together higher level networking with bread and butter issues on the ground with varying degrees of success. They have often operated outside of traditional industrial relations frameworks with a flexible repertoire including social dialogue, corporate responsibility and private governance. This flexible practices of scaling up union activity has, to varying degrees crated new union subjects with different geographical scopes and new forms of trade union action. While these activities are clearly constrained by previously established institutional frameworks and exclusionary practices they do indicate that through rescaling at a national level novel forms of struggle can emerge. What begins as an informal, even hesitant, process driven by this process may be throwing up new forms of industrial relations and ways in which labour can contest the rule of capital.

Elísio Estanque and Víctor Climent in turn examine labor and informal work in north-south relations through a comparative study of the Iberian countries and Latin America analyzing trends, contrasts and assymetries based on different scales. The growing phemonena of informality and labour precarity at a global scale is seen to have particular regional impacts and modalities at the EU and regional Latin American levels. The recent and growing challenges of technological innovation and digitalization are thus placed in their particular regional settings. This article reports on an ongoing project in Latin America developing sociological knowledge in a university setting that engages with trade union organisations. They argue that there is a specific Latin American context in which these global processes play out, shaped by the colonial heritage and its ongoing impact on labour relations and the nature of late peripheral industrialization. The study and the ongoing research project seeks to contribute to our understanding of the way in which global capitalism is at 
a crossroads due to the brutal impacts of the Covid-19 pandemic and the increasing need for decent work in which North-South dialogue can play an important role.

The issue of platform workers in Latin America in terms of transnational logics and the regional resistances it engenders is examined by Pablo Miguez and Nicolas Diana Menendez in a study which examines the six most important delivery and ride services, as well as travel platforms (Uber, Cabify, Rappi, Glovo, Pedidos Ya), and the embryonic collective organizing of platform workers that has emerged in recent years. This has not been carried out, on the whole, by existing unions but rather through the independent organizing efforts of the platform workers themselves. These workers, that include drivers, motorcyclists and bikers have organized in ways that have been inspired by global best practice and articulating a number of novel repertoires of action. We note an important presence of migrant workers in the services such as mail, postal services and the transport of people. This type of organizing in some ways take us back to the early period of the industrial revolution before the emergence of what today are called industrial relations. The Covid-19 pandemic has intensified the degree of exploitation and precarity of these workers whose struggles reflect the past but also, arguably, the future of labour organizing.

\section{Ways forward}

Current debates on the way forward for labour tend to be rather polarised. On one side are many analysts, both conservative and radical, who believe that labour, as a relevant social actor, is an anachronistic idea and that labour unions are an archaic organisational model, not relevant in our postmodern globalised world. It is understandable that pro-market fundamentalists will emphasize any way in which unions, as collective organisations, may no longer be relevant. The neoliberal theoretical revolution of the 1990s was based precisely on the virtues of the market and the evils of collectivism. There is also a radical approach to "the crisis of world labour", well exemplified by Marcel van der Linden, who argues that "both old-style trade unionism and old style worker's parties can no longer cope with the challenges offered by the contemporary world" (Van der Linden, 2015, p. 10). This, in itself, is correct, but he then goes to argue that the global union density of $7 \%$ worldwide, as well as the decline of the global capital/labour ratio, makes the task of confronting the new global order extremely difficult if not impossible. I think this analysis is one-sided, in that it focuses only on some very broad - and inevitably partial - aspects of how labour organises globally.

Contemporary critical thinking is still strongly influenced by binary oppositions, a system which, in language and in thought sets up two theoretical concepts defined 
strictly in relation to each other. Thus we have seen the opposition set up in the critical literature between the "old" and the "new" social movements. The first, of which labour is the paradigmatic example, is deemed bureaucratic and stale whereas the "new" movements are seen as democratic and vibrant. A whole set of related binaries could be mentioned: state versus civil society, North versus South, top-down versus bottom up, and, of course, local versus global. All these binary oppositions are characterised by a presence-absence dichotomy and relation of dominance. The political critique of binary oppositions - as practised throughout this book - is not simply the reversal of the opposition but its deconstruction. The problem of logocentrism - words as a fundamental expression of an external reality - which lies behind those binary oppositions are often ethnocentric and they are as much an issue on the left (as in local=good) as on the right of politics.

Just one, quite technical, term we could deconstruct is that of "trade union density" across time and space. Most often this apparently simple indicator is used to show that unions are in terminal decline, at least in the advanced industrial societies since the onset of neoliberal policies in the 1980s. Yet union density is not the only factor affecting the bargaining power of a union. Employer/state negotiations are equally important, not to mention political power. John Kelly goes further in decoupling union density from the prospects for union revitalization, arguing on the basis of complex data that "despite the problems they have faced in recent years and their denigration as a merely sectional interest group, unions remain a powerful force both for egalitarianism and for democracy" (Kelly, 2003, p. 21). In shaping their role in society, unions may reshape their identity and goals, fundamentally altering their economic, political and social roles.

So, moving forward "beyond the impasses" we can see for example that it is not a question of counter-posing a pessimistic analysis with an optimistic one; that would be a poor critical response. But, a longer term analysis of the making and remaking of the global working class and its organisations over time, from a broadly Polanyian "double movement" perspective, would provide an alternative framework. As against the fairly static negative view outlined above, the emphasis here is placed on the dynamic and dialectical nature of the capital/wage-labour relation. Thus Beverly Silver stresses how "one of the key driving forces behind [capitalism's] tendency towards 'ceaseless change' is labour - capital conflict" (Silver, 2003, p. 49). If capitalism, as we know it today, in its informationalised and globalized form, is in part due to historic labour resistance, then capitalism has not leapt beyond its dependent relationship with labour, established during the Industrial Revolution. Each time workers' bargaining power is weakened by technological advances or relocation to low wage regions, this contradiction comes to the fore once again. 
The Polanyian frame was one which made sense around 2000, not because it was "optimistic", but because it allowed us to capture the significance of seemingly disconnected signs that the one true model of market driven globalisation was being contested. It seems wrong to see this as an example of the "Pollyanna principle" (a subconscious bias towards the positive) as Burawoy argues somewhat less than constructively (Burawoy, 2010). Burawoy's attack on "the false optimism of global labour studies" argues that the adaptation of the Polanyian "double movement" hypothesis leads inevitably to an unfounded optimism around the prospects for labour successfully responding to neoliberal globalization. Apart from an unnecessary attack on the practitioners of the new global labour studies and a disabling pessimism which sees all resistance as futile, Burawoy does make a rational point. Burawoy argues that we first need to decide" where one sits in relation to.... exploitation [Marx] or commodification [Polanyi] - [will] dictate the strategy one deploys in moving forward" (Burawoy, 2010, p. 307). We can either promote transnational labour alliances or local alliances embracing all impacted by market-driven commodification he argues. In reality, this binary opposition presents no such stark choice, workers make alliances across national borders and, often at the same time, with broad social and community layers nationally in pursuit of social movement unionism.

There is, notwithstanding, the somewhat inflated nature of the optimism/pessimism binary, a real problem with the way in "which the new global labour studies (this author not excepted) builds general pictures of 'labour and globalisation' based on somewhat scarce empirical material". As Brooks and Mc Callum note in a review of the field "the labour as counter-movement strand [of the new global labour studies] suffers from a tendency to assume that several individual instances of transnational action comprise a single global movement" (Brooks \& Mc Callum, 2017 , p. 202). Many instances of cross-national organising and international bargaining have actually ended in failure, something not usually noted in triumphalist accounts. There has been since 2000 a veritable explosion in concrete studies of transnational labour action which need to be integrated into the "bigger picture" of the Polanyian counter-movement thesis, to prove or disprove its assumptions. In short a facile optimism is an inadequate answer to the debilitating pessimism of Burawoy for example. The articles contained in this special issue help us move beyond simplistic divisions between pessimistic and optimistic frames, they recognise that workers make their own history but not under conditions of their own choosing.

Stefan Schmalz, Teresa Conrow, Dina Feller and Maurício Rombaldi pose a discussion on new forms of transnational labour organizing around case studies of two global union federations. The Building and Woodworkers International (BWI) has adopted a high profile event-based form of organizing focusing on mega sport 
events like the Fifa World Cup or the Olympics. In the immediate lead in to these events the trade unions have a strong platform to initiate local struggles for wages and working conditions but from a multi-scalar perspective insofar as pressure is applied globally on the construction companies. The international Transport Workers Union (ITF), in turn, has developed a network-based organizing approach which brings together transport unions in transnational company or industry-wide networks. The transport sector workers have traditionally been able to have high impact due to the vulnerability of global production networks to focused labour actions. These two forms of organizing show there are different ways to connect the local with the global, but neither is successful without local associational power. In brief. while the Global Union Federations have become key agents in terms of transnational labour organizing they cannot replace local organizing and need to act in synch with these for this strategy to be successful.

Hermes Augusto Costa and Bia Carneiro, for their part, offer a consideration of digital communication as a global challenge for trade unions through case studies of Brazil and Portugal. They see the cross cutting issue of digital technologies as challenge to traditional trade union practice that still sees face-to-face communications as the norm. They present the very real possibilities that the social media offer a forward looking strategy for organized labour. Through a comparative analysis of the digital media presence of four trade union confederations - two in Brazil and two in Portugal - they find that the traditional trade union approach to digital communications still prevails. Despite the possibilities offered for inner union communications and, crucially, communications with non union social movement actors, this has not been taken up in any decisive way. The way these federations maintain constricted communications networks and an outdated top-down communications model does not augur well for the transformation of unions in a social movement direction. The way forward clearly involves an embrace of networked digital communications as technology and political practice.

Warren Mcgregor and Edward Webster, for their part, discuss the building of a regional solidarity network of transnational activists through an African case study with a focus on the role that can be played by worker education. A network of transnational activists was initiated by the Global Labour University across Sub-Saharan Africa dedicated to the development of skills for a new type of union organiser. The authors show how this network has helped forged solidarity across national boundaries and regional frontiers through educational work and the promotion of campaigns to strategize and put into action new forms of transnational solidarity. It is the alumni of the GLU courses that form the backbone of the activist network of labour activism that are then brought into contact with other labour activists 
and labour organisation. What this experience shows is the general importance of a labour strategy that is able to navigate the local and the global at the same time, going global does not do away with the need to remain local. There is a long tradition of labour education and it has always built capacity amongst workers and fostered the ethos of solidarity. What this example also shows are the huge challenges in terms of scale when faced with the reality of capitalist and imperialist power.

Another approach to a way forward for labour is advanced by Jörg Nowak who examines the nature of global economic planning as a challenge for the labour movement. The basic argument is that the needs of the current conjuncture are of such urgency and magnitude that they cannot be answered by current institutional strategies such as the Decent Work agenda or the building of more Global Framework Agreements. Nor will the current turn towards a new industrial strategy to respond to the failings of the market driven de-industrialising liberalism suffice. What is needed from this perspective is a new strategy of global economic planning that could map the operations of the transnational corporations and then provide an avenue for the labour movement to intervene in key issues such as climate change based on mass participation. It could take up specific issues such as the conversion of the automobile industry and the creation of community based health systems, an obvious need in the light of the Covid-19 crisis.

Fernando Elorza Guerrero and Manuel García Muñoz examine Eu conditionality and trade union action in the promotion and defence of workers' rights through an examination of the Spanish case. There was, for a time a belief in Europe that the move towards supra-national decision making by the Troika (conditionality) would substitute for the national social contract and lead to a radicalization of labour and other struggles. However, the Eu modified its early centralised and imposed financial rescue plans for countries that needed them (such as Greece, Ireland, Spain etc.) and opened up a more participatory and dialogic dynamic. At that point most trade unions decided to engage critically with that sort of reconstruction process within the well-established social partnership mechanisms that brought them into dialogue with the state and employers' associations. In this way the more radical possibilities of a broad social alliance between labour and civil society was foreclosed and alternative to predatory capitalism was not even discussed. This is not surprising insofar as labour has always been part of an industrial relations apparatus that acts to dampen the class struggle, a fact of life in the global South as much as in the EU.

Dimitris Stevis addresses the crucial question of the globalization of just transition in the world of labour in terms of the politics of scale and scope. Key questions are posed that are vital for the future of the labour movement and inescapable for the "what is to be done" agenda. The just transition agenda seeks to breach the historic 
green/red divide and take labour to the heart of the environmental question. Some variants of environmentalism, for example those that downplay environmental dispossession, that are in danger of marginalizing working class communities and even drive them into the arms of polluting capital. Nor can we mechanically add up environmental issues if each union has a position on its industry. The just transition approach seeks to build a social and an ecological synthesis (along the lines of the Green New Deal) where both carry equal weight and through which we can identify the social equity aspect of ecological goals. The depredations of late global capitalism have an impact on the environment and also on workers, their families and communities. Forging a common agenda is probably the main issue facing the labour movement on a global scale today.

Building on the studies contained in this collection and looking back at the thirty years or so since globalization made its entry into the social sciences as well as global politics, we can see how it has created as many opportunities for labour as it has caused problems, or closed off traditional avenues for contestation. Peter Evans, amongst others, has stressed how "globalization, both as generic shrinking of geographic and social space, and in the form of specific structures of the contemporary neoliberal capitalist political economy, stimulates and facilitates the mobilization of labour solidarity at the transnational level, as well as the construction of labour movement organizations and networks" (Evans, 2014, p. 356). If capital can reinvent and revitalize itself, so can labour and its organizations, that should never be seen as static.

Antonio Gramsci - a labour activist and leader before he was a theorist - wrote in relation to the "modern crisis" of the 1930s: "the crisis consists precisely in the fact that the old is dying and the new cannot be born" (Gramsci, 1971, p. 276). The old ruling class had lost its consensus, was no longer "leading" or hegemonic. And yet, the new class - the workers - and their organisations were not ready to take power, even though "the great masses have become detached from their traditional ideologies, and they no longer believe what they used to believe previously" (Gramsci, 1970, p. 276). We can I think adapt his model to the post 2000 situation and, in particular the post Covid-19 we are now entering.

The other strand of analysis we need to foreground, to break beyond the current impasse, is a long term view of labour's relation with democracy. For Gerald Friedman "the labour movement began as a popular struggle for democracy" (Friedman, 2007, p. 15) and, if it is to have any meaning today, it needs to renew that commitment. Labour - as a social category and as a social movement - basically advances a project for social, economic and political democracy. What the ideas of the French Revolution - liberté, égalité, fraternité - meant for the original labour movement, perhaps today the ideas of the global justice movement could provide similar inspiration for 
labour. The success of the trade union and labour movement in the past was based on organization and solidarity to create a genuine community of interest. Turning away from spontaneity and grass roots democracy leads only to bureaucratisation, demoralisation and ultimately decline - because this is hardly a social movement that will attract new members. But if labour is a social movement (and that is of course debatable), then it has the capacity to renew and reinvent itself so as to meet the new challenges of the era.

\section{References}

Brooks, M. \& Mc Callum, J. (2017), “The new global labour studies: A critical review”. Global Labour Journal, 8 (3): 201-218.

Burawoy, Michael. (2010), "From Polanyi to Pollyanna: The false optimism of global labor studies". Global Labour Journal, 1 (2): 301-313.

Canguilhem, G. (1991), The normal and the pathological. New York, Zone Books.

Cook, M. L.; DutTa, Madhumita; Gallas, Alexander; NowaK, Jörg \& Scully, Ben. (May 2020), "Editorial global labour studies in the pandemic: Notes for an emerging agenda". Global Labour Journal, 11 (2).

Evans, P. (September 2014), "National labour movements and transnational connections: Global labour's evolving architecture under neoliberalism”. Global Labour Journal, 5 (3): 258-282. Available at https://escarpmentpress.org/globallabour/article/view/2283.

Guardian. (2020), “'Great lockdown' to rival great depression”, The Guardian (14 April 2020), available at www.theguardian.com/business/2020/apr/14/great-lockdowncoronavirus-to-rival-great-depression-with-3-hit-to-global-economy-says-imf.

IMF (International Monetary Fund). (2020), “A crisis like no other, an uncertain recovery”, available at www.imf.org/en/Publications/WEO/Issues/2020/06/24/wEOUpdateJune2020, accessed 21/09/2020.

KeLly, J. (2003), Labour movement revitalization? A comparative perspective. Dublin, Countess Markievicz Memorial Lecture.

Mazzucato, M. (18 March 2020), "The Covid-19 crisis is a chance to do capitalism differently". The Guardian, available at www.theguardian.com/commentisfree/2020/ mar/18/ the-covid-19-crisis-is-a-chance-to-do-capitalism-differently, accessed 01/07/2020.

MERRIAM-WEBSTER. (2020), "Definition of crisis". Available at www.merriam-webster.com/ dictionary/crisis\#, accessed 01/07/2020.

SiLver, B. (2003), Forces oflabour: Workers'movements and globalization since 1870. Cambridge, Cambridge University Press. 
Solnit, R. (2010), A paradise built in hell: the extraordinary communities that arise in disaster. New York, Penguin.

Solnit, R. (2020), "The impossible has already happened: what coronavirus can teach us about hope". The Guardian. Available at www.theguardian.com/world/2020/apr/07/ what-coronavirus-can-teach-us-about-hope-rebecca-solnit, accessed 01/07/2020.

TAYLOR, R. (2019), The psychology of pandemics preparing for the next global outbreak of infectious disease. Cambridge, Cambridge Scholars Publishing.

Tooze, A. (2020), "Shockwave”. London Review of Books, 42 (8). Available at www.lrb. co.uk/ the-paper/v42/n08/adam-tooze/shockwave, accessed 01/07/2020.

VAn Der Linden, Marcel. (2015), “The crisis of world labour”. Against the Current, 176.

\section{Abstract}

Labour and globalisation: complexity and transformation

As a matter of balance of the contributions joined in the Dossier, this final word draws a comprehensive picture of the issues discussed by the authors and raises some questions pointing to a possible agenda for current labor studies. First, it sparks reflections going in the sense of discussing the actual meaning of what is to be considered either "normal" or "healthy" after Covid-19 crisis. Then it addresses such discussion to the world of work with interesting consequences, asking what is actually "normal" in labor relations. In the same vein, it reminds us the role of the so-called "essential workers" during the sanitary crisis: a lot of invisible realities which are now becoming visible. On the other side, the author call attention to imminent economic crisis, affecting jobs and companies. Similarly, he warns about the worsening of the working conditions under a post-Covid world: no "return to normal" is envisioned without shaking important structures of the already-known world. One of those pillars is the North-South divide: according to the author, that divide is loosing because the neat two-worlds mapping is blurred today - we find informality on both "worlds", as well as either digital economy and inequalites are present North and South, so clear-cut differences may tend to disappear. The author finally proceeds to make a short comment about every of the contributions to the dossier, pointing out what is crucial and distinctive in each of them.

Keywords: Post-Covid; Normal and pathological; Essential workers; North and South.

\section{Resumo}

Trabalho e globalização: complexidade e transformação

A título de balanço conclusivo das contribuições reunidas neste Dossiê, o artigo traça um quadro abrangente dos tópicos discutidos pelos autores e levanta algumas questões que apontam para uma possível agenda de estudos sobre o mundo do trabalho hoje. Inicia refletindo sobre o sentido de se discutir o significado real do que deve ser considerado "normal" ou "saudável" após a crise 
do Covid-19. Em seguida, direciona a discussão para o mundo do trabalho, com consequências interessantes, questionando o que é de fato "normal" nas relações de trabalho. Dentro do mesmo diapasão, é lembrado o papel dos chamados "trabalhadores essenciais" durante a crise sanitária, quando muitas realidades invisíveis se tornaram visíveis. Por outro lado, o autor chama a atenção para a crise econômica iminente, afetando empregos e empresas. De forma similar, alerta sobre a piora das condições de trabalho em um mundo pós-Covid: nenhuma "volta ao normal" pode ser concebida sem um abalo das estruturas importantes do mundo tal como existe. Um desses pilares é a divisão Norte-Sul: de acordo com o autor, tal divisão está se afrouxando, pois o desenho de dois mundos estanques está hoje menos nítido - encontramos informalidade em ambos os "mundos", bem como a presença da economia digital e das desigualdades, que estão presentes tanto no Norte quanto no Sul, de maneira que as diferenças tendem a desvanecer. Por fim, o autor passa a comentar uma a uma cada contribuição para o Dossiê, apontando o que é crucial e distinto em cada uma delas.

Palavras-chave: Pós-Covid; Normal e patológico; Trabalhadores essenciais; Norte e Sul Global.

Texto recebido em 4/5/2021 e aprovado em 19/5/2021.

DOI: $10.11606 / 0103-2070 . t s .2021 .185370$.

RoNALDo MUNCK is professor of sociology and director of the Centre for Engaged Research at Dublin City University and an active shop steward for Siptu. He is author of Rethinking global labour: After neoliberalism, Agenda Publishing, 2017. E-mail: ronnie.munck@dcu.ie. 